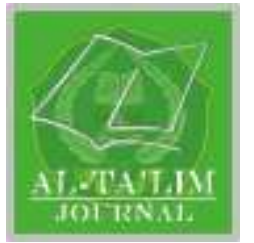

AL-TA'LIM JOURNAL, 24 (2), 2017, (79-92)

(Print ISSN 1410-7546 Online ISSN 2355-7893)

Available online at http://journal.tarbiyahiainib.ac.id/index.php/attalim

\title{
Peaceful in Pesantren: The Involvement of Santri's Peaceful Environment and Personality
}

\author{
Received:14 ${ }^{\text {th }}$ February 2017; Revised:26 ${ }^{\text {th }}$ February 2017; Accepted: $25^{\text {th }}$ July 2017
}

Permalink/DOI: http://dx.doi.org/10.15548/jt.v24i2.252

\section{Ade Hidayat}

Universitas Mathla'ul Anwar Banten, Indonesia.

E-mail: adehidayat@unmabanten.ac.id

\begin{abstract}
The aim of this study is to identify the characteristics of peaceful personality of adolescent Santri (Islamic students) and their peaceful environment. The subjects of the study are 57 respondents taken from two classes (both male and female classes) of the $11^{\text {th }}$ grade in Madrasah Aliyah (Mualimin) Pesantren Persis 19 Bentar Garut, academic year 2015-2016. Quantitative research was used where the data was analyzed descriptive and correlational statistics. The result of the study showed that average achievement of peaceful personality is considered high in the aspects of intrapersonal and interpersonal peaceful personality. The number of Santri's perceptions on the condition of Pesantren's (Islamic school) peaceful environment is also considered high. The factor of the environmental condition in Pesantren and home, according to the result of study, significantly influences the peaceful personality of adolescent Santri.
\end{abstract}

Keywords: Adolescents, peaceful environment, peaceful personality, Pesantren.

How to Cite: Hidayat, A. (2017). Peaceful in pesantren: the involvement of Santri's peaceful environment and personality. Al-Ta Lim Journal, 24 (2). doi:http://dx.doi.org/10.15548/jt.v24i2.252

\section{INTRODUCTION}

One of human's psychological needs is the presence of peaceful sense either in relation among family, communal, and nations. Individually, human seeks peace within himself both psychologically and spiritually (Isnaini, 2013; Meria, 2012; Mujidin, 2012). It is clear that basically, based on human egoistic justification, human loves peace in which everybody has such feeling that should be developed.

In the 1960s, the context of peace was firstly functioned as a prevention of war, resolution of conflict, prevention of nuclear threats, as well as the improvement of democracy and structural violence (Farmer et al., 2004; Harber \& Muthukrishna, 2000;
Sims, Nelson, \& Puopolo, 2014; Wulf, 2004). However in the last decade, when discourses on peace were more focused on discussing peace of community, as if individual peace was neglected, at present, the attempts to introduce the concept of inner peace have been made at the level of manifestation and psychology. Therefore a specific study of personal peacefulness and peaceful personality is developing today.

Peaceful Personality is defined as a personality trait, condition, and attitude of individuals (Nelson, 2014b, 2014a). Peaceful personality refers to act of giving birth to harmony and maintain nonviolent or harmonious relationship. The conditions of peaceful personality include a sense of calm, comfortable, safe with the presence of 
harmony, in particular aspects. Peace-loving attitude is a belief or conviction that creates a harmonious and non-violent relationship.

A various number of studies on peace are believed as an invention of selfconsciousness considering the history of humanitarian that experienced crisis questioned the presence of peace during wars, like the world war, cold war, nuclear weapons, mass murder, and killings that happen all the time. How can violence be tolerated in human lives, if it creates the extinction of human? Considering that there is no single religious teaching and belief in the world that gives legitimacy to violence (Hufad, 2003; Isnaini, 2013; Jackman, 2002). Life or peaceful path has become necessary, since it is now a sociological, psychological, and spiritual demand in all religions (Rusydiyah, 2014; Trinova \& others, 2016).

Peaceful path or non-violent path is an action that use power and influence to achieve one goal without hurting or being cruel to another individual. The principles of the path are: believing that revenge and violence should be avoided, wanting to understand truths in a conflict, sacrificing for the breaking of the chain of violence, making sure not to get involved in any crime or violence, as well as participating in the prevention of injustice that will result in the birth of social justice consistently without the use of violence (Mayton, 2009; Wheeler et al., 2009). The characteristic of peaceful or non-violent personality according to Gandhi (2012) is being an anti-physical violence, anti-psychological violence, empathy, being firm to seek truth (satyagraha), and willing to sacrifice (tapasya).

Inner peace within an individual is a core domain that supports the structures of interpersonal interaction. A Peaceful social relation of an individual with other person is determined by whether or not the individual finds peace within himself, and the influence of both relationships is reciprocal (Aron, 2003; Elias, 2001; Misztal, 2013). Peaceful personality is a combination of four components (diamond model) or anti-violence levels, namely anti violence of intrapersonal, interpersonal, social and world (Mayton, 2009).

The respondents of this research are teenagers, in which the researcher took two components of peaceful personality to be analyzed, namely intrapersonal and interpersonal peace. Both intrapersonal and interpersonal aspects of peace form the patterns of peaceful personality of adolescents that their relationship with peaceful situation or condition of respondents both at school and home will be further analyzed.

Intrapersonal peace as self-acceptance character includes self-failures, appreciates self-uniqueness and has its own selfassessment (Nelson, 2014b). It is not easily distracted by others' judgment, cares for himself, understands his own imperfections, keeps his feelings under control, is always in peaceful state with his soul and deals with his inner conflicts, so he tends to face reality in a calm state, while having him corrected. Meanwhile, interpersonal peace is a character of a set of positive attitudes towards others characterized by following traits: accepting others as who they are, being friendly and polite, being altruistic and happy to help others, and willing to adjust for differences in order to reach an agreement, selflessly wanting to create a better condition both physically and mentally for others, and always avoiding hostility and aggression.

Peaceful personality is closely related to psychological health (Christie, Wagner, \& Winter, 2003) (Christie, Wagner, \& Winter, 2003). Physical and psychological health conditions which are optimal are formed when personality aspects are harmoniously integrated. Meaningfulness of life is found when someone undergoes activities and plans in accordance with his own value, commitment, and self-personality (Kroger, 2007; Singh, 2008; Smith, 2006).

Adolescents have a need to find a meaningful life. Religion and education are a 
form of life institutions that include many life principles that imply the meaningfulness of life. One of them is peace. Idealism of peace or a peace-loving personality is a primary value in every religion. All religious doctrines always inspire peace and happiness for their own believers in particular, and all people in general, either vertically or horizontally, both spiritual and physical happiness. In line with religions, education also has similar value to religions in guiding humans' lives.

The miniature of human development concept is regulated by education and religion in pesantren life (Islamic school). Pesantren is a cultural formal institution where education and religion are synergized to score educated generations. Pesantren supervises and teaches their adolescent students so that they can transform into someone who loves peace and believes in God. This means that there is a two-way interaction between spiritual and social relationship.

Pesantren in Indonesia becomes a tradition and a primary option for those who want to study Islam. The lessons pesantren teach that are more focused on teaching morality (akhlak), religious understanding and intensification of worship (fiqh), and revamping of belief (faith) show that the presence of pesantren is to map a great tradition (Asnawir, 2012; Nugroho, 2012).

Pesantren as an Islamic-based educational institution is an institution of education in transforming knowledge, normative values, universal concept of humanity, good life procedures, both spiritually and socially, as well as the usefulness of life meaning by finding the right life purposes within the individuals.

Aqidah and Ahklak teachings transfer values, morals, manners, characters, manners to parents, teachers, neighbors and natural environment, as well as honesty, diligence, and so forth. Tauhid teaching deals with spiritual reinforcement, where the concept of monotheism controls individual's soul not to subject to any domination of any kind, but to believe in the presence of the Divine (transcendent) who is full of justice and compassion (Asmaul Husna). Tarikh teaching is mainly about history of Islam that is related to social justice, equality and universal brotherhood. Koran and Hadith lessons teach students about the importance of norms, values and God's guidance, as well as prophetic basis in their lives.

The definition of Islam under the framework of the mind of liberation theology is a religion in a technical sense and sociorevolutionarily that threatens the oppressing structures (An-Na'im, 2002; Bayat, 2007; Moosa, 2001). The basic objective of Islam is to realize universal brotherhood, equality and social justice, in which they are conditions to form a peaceful society.

In Islamic teaching, a Muslim character building is constructed in gradual stages. The foundation stage is the aspect of Tauhid. It is a complex and strong divine mechanism as the basis to build a Muslim character to strongly face life challenges. Muslim character is to accept and surrender to God (aslam) to live in Islamic ways of life which are good and right, in order to embrace life goals, and here lies the happiness of a Muslim. Research shows a positive correlation between self-acceptance and happiness, life satisfaction, positive influence and the finding of life purpose (Diener, $\mathrm{Ng}$, Harter, \& Arora, 2010; Diener, Oishi, \& Lucas, 2003; Ryff \& Keyes, 1995; Ryff \& Singer, 1996)

In the pursuit of life goals, a Muslim must focus on Tauhid. Tauhid as the application of spiritual monotheism contains liberation of the soul from tyrannical hegemony, to God's absolute hegemony that will liberate humanity. In psychological interpretation, this concept serves as the maintenance of peace in the inner self from wild external determinants. After this stage is reinforced, the next stage is more into social relationship (muamalah). This stage deals with lots of rules, regulations and norms to be followed that aim to create a peaceful social 
life. Socially, the objective of Islamic rules is to preserve every life of human being, social balance in various social elements, as well as the maintenance of individual rights (AnNa'im, 1996; ash Shiddieqy, 1999; Dusuki, 2008; Halstead, 2004; Hanafi, 2002), thus a harmonious society is actualized.

Adolescence is a phase after childhood that every human being has to get through. Adolescence is a transition of developmental period between childhood and adulthood that includes biological, cognitive, and socialemotional changes (Blakemore \& Choudhury, 2006; Gavazzi, 2013; Norcross, Campbell, Santrock, Selagea, \& Sommer, 2013; Sameroff, 2010; Sawyer et al., 2012; Zarrett $\&$ Eccles, 2006). Adolescence is a phase full of dynamics, in which a large psychological conflict may occur. The dynamics of the search for identity with a high sense of curiosity and psychomotor maturity that can surpass cognitive-affective maturity in controlling emotions put most teenagers in risky conditions. If these factors are focused and able to sustain the growth and development of adolescents in a positive way, it will result in the completion and optimization of the development tasks for a healthy and harmonious social life. However the opposite condition sometimes occurs, unhealthy relationships that lead to social collisions occur due to negative dynamics of adolescence, then what happens is a condition full of violence and loss of peace?

Based on problems explained previously, the present study aims to identify more about inner peace from the perspective of psychological dimensions of Pesantren (Islamic school) that instills peace, to reveal the students' perception about peace based on their experiences at school and home, as well as to investigate the characters of peaceful personality owned by students in their interaction with environment. This is important to be explained in this study in order to explore fundamental basics about the peaceful personality of adolescent students; supporting aspects and the barriers; a completed description that helps researcher to have a deep comprehension and able to handle problems, as well as application of the solution to the problem of students. Therefore, the aim of this study is to: (1) identify a conception about peaceful personality of the students, (2) investigate the relationship between peaceful personality and peaceful environment of the students.

\section{METHOD}

Descriptive quantitative approach with non-experimental correlation method was used in this study. The correlation study aims to investigate the relationship between one variable and another variable (Sukmadinata, 2007). The relationship between environmental variables and peaceful personality is statistically presented as coefficient correlation and significance.

The study was conducted at Pesantren Persis 19 Bentar Garut Tingkat Mualimin (Madrasah Aliyah). The subjects of this study were the entire students of the eleventh grade in academic year of 2015-2016, that includes 29 male students, and 28 female students. Considering the numbers of the population are not many, the entire population as many as 57 students were sampled in this study (Arikunto, 2002)

The instruments used to collect the data were two kinds of questionnaires on perception of peaceful personality and peaceful environment; both questionnaires are compiled by the researcher. The design of this study is vicariate correlation, used to prove the relationship between cause and effect of environmental variables and peaceful personality of students.

This study was carried out following these procedures: (1) Formulation of problems. The selected issues have a significant value in pattern of this complex behavior phenomenon that needs a further understanding. Both variables were selected in the study based on theoretical and logical considerations; (2) A review of related literature, conducted to find the foundation of 
theoretical basis, framework of study and hypotheses; (3) Targeting the respondents of study; (4) Data collection through questionnaires, in which the respondents' perceptions on peaceful personality and environment were measured; (5) Selection of data, that aims to decide adequate data to be processed. The collected data must be equal to the numbers of distributed questionnaires; (6) the scores of collected data in this study are arranged in the form of an ordinal scale that shows the different levels of respondents quantitatively (Furqon, 1999; Siregar, 2005).

The scoring of each item of statements is based on the options and the nature of each statement (positive or negative) with a range of scores between 1 to 8 for a peaceful personality instruments, and 1 to 5 based on students' perceptions of peaceful environmental conditions both at school and homes; (7) Analysis of the data, using vicariate correlation technique to calculate the level of relationship between environmental variables and the peaceful personality of students. The results of the analysis are reported in the form of correlation coefficient and significance levels, and the proportion of variances contributed by the environment variables to the variable of peaceful personality.

The technique of data collection used in this study is through questionnaires. The form of the questionnaire used is a structured questionnaire with a closed form of answer, in which the answers are provided, and the respondents only have to answer each question by choosing the alternative answers provided. The questionnaire of peaceful personality applies semantic differential scale, whereas the questionnaire of peaceful environment perception applies Likert scale model.

The questionnaire content of peaceful personality was based on intrapersonal and interpersonal aspects of peace. Intrapersonal peace includes sub-aspects of self-acceptance, self-compassion inner harmony. Interpersonal peace includes sub-aspects of hospitality (agreeableness), cooperative, pro-social, and non-aggressiveness.

The questionnaire of the perception of peaceful environments at home and Pesantren, includes the perceptions of students about a state of calm, safe and comfortable when dealing with family members at home (parents and siblings) and Pesantren (friends and teachers/assatidz), characterized by the absence of violence, the presence of acceptance (tolerance), justice, and healthy communication.

Before being used to collect the data of study, firstly the questionnaires had to be validated, both the contents and the forms. The validation process of the content and forms involved experts' judgment to assess whether the material has been in accordance with the concept that will be measured, or not. Once the questionnaires are validated by the experts, the instruments are then tested.

The pilot study was conducted involving the tenth grade of male students as many as 40 students of Madrasah Aliyah Persis 19 Bentar, Garut. The pilot study was conducted to measure the validity and reliability of the instruments. The results of the validation test towards peaceful personality questionnaire, was based on correlation coefficient score from 22 items prepared. There were four items invalid, i.e. 2, 4,14 , and 19. The four items were not valid since the r-count is smaller than r-table which is 0.312 (df: 38 with a significance level of $0.05)$.

Since the item number $2\left(\mathrm{r}_{\text {count }}=\right.$ $0.83)$, no. $4\left(\mathrm{r}_{\text {count }}=0.036\right)$, no. $14\left(\mathrm{r}_{\text {count }}=\right.$ $0.221)$ and number $19\left(\mathrm{r}_{\text {count }}=0.156\right)$ are considered invalid, the four items were removed, thus there are 18 items used in the study. The reliability test of this personality instrument applies Split-Half models having the other four items removed considering that they were invalid. Based on the calculation, the peaceful personality questionnaire had a reliability coefficient as much as 0.934 . Based the categorization formulated by Guilford, the 
score is categorized very high (Ruseffendi, 2005), thus, the developed questionnaire of peaceful personality is very dependable to be used as the instrument of this study.

The results of the pilot study with the same validation testing, among 8 items prepared, all of them are considered valid, because the $\mathrm{r}_{\text {count }}$ of all items were greater than the rtable. The reliability test applied Split-Half models. Based on the calculation, the questionnaires of peaceful environment perception have reliability coefficient about 0.595 , or categorized average. Thus, questionnaire developed can be used as a research instrument.

\section{RESULTS AND DISCUSSIONS}

\section{Characteristics of Students' Peaceful Personality}

The characteristics of peaceful personality of students were collected from the questionnaires that were distributed to the students of class XI Pesantren Persis 19 Bentar Garut. The results of study are empirical descriptive about the picture of peaceful personality of students that consist of: (1) General picture of peaceful personality of students; (2) the picture of the peaceful personality of students based on several aspects. (3) Students' perception on their peaceful environmental conditions.

The general characteristics were collected from the 57 respondents. The picture is generally described by percentage based on the criteria scores presented in Table 1 .

Table 1.General Picture of Student Peaceful Personality

\begin{tabular}{lccrr}
\hline Category & $\begin{array}{c}\text { Score } \\
\text { Range }\end{array}$ & $\begin{array}{c}\text { Score Range } \\
(\boldsymbol{\%})\end{array}$ & F & \multicolumn{1}{c}{} \\
\hline Very Low & $18-72$ & $12.5-50.0$ & 2 & 3.51 \\
Low & $73-90$ & $>50.0-62.5$ & 7 & 12.28 \\
Medium & $91-108$ & $>62.5-75.0$ & 12 & 21.05 \\
High & $109-126$ & $>75.0-87.5$ & 21 & 36.84 \\
Very & & & & \\
High & $127-144$ & $>87.5-100$ & 15 & 26.32 \\
& Total & & 57 & 100.00 \\
\hline
\end{tabular}

The mean of all scores is 111.23 or higher category. However the achievement of these scores is prone to slip in medium category, so it needs a serious effort to improve the behavior and peaceful personality of students. The scores above are in accordance to students' answers when asked about whether they have done any rude behavior or fights with their friends in the last one year. There are 37 respondents who never have any fights with their friends (physically) in the last one year. A total of 15 respondents did 1-3 times, there are three respondents did 4-6 times, and 7-10 times by one respondent, and another one respondent did more than 10 times.

To get a more specific description, the peaceful personality of students is presented in Table 2 based on two aspects of the personality, namely aspects of intrapersonal and interpersonal peace.

Table 2. The Overview of Students' Peaceful

Personality Based on Following Aspects

\begin{tabular}{llcl}
\hline No. & Aspects & $\begin{array}{c}\text { Average } \\
(\boldsymbol{\%})\end{array}$ & Category \\
\hline & $\begin{array}{l}\text { Intrapersonal } \\
\text { Peace }\end{array}$ & 78.02 & High \\
& $\begin{array}{l}\text { Interpersonal } \\
\text { Peace }\end{array}$ & 76.46 & High \\
\hline
\end{tabular}

Table 2 illustrates the peaceful personality in the aspects of intrapersonal peace that are in high category with the mean score is $78.02 \%$. Similarly interpersonal aspects of peace is also categorized high with the mean score is $76.46 \%$.

Table 3. The Overview of Students' Perception on Peaceful Environmental Conditions

\begin{tabular}{llcc}
\hline No. & \multicolumn{1}{c}{ Aspects } & $\begin{array}{c}\text { Average } \\
(\%)\end{array}$ & Category \\
\hline 1. & $\begin{array}{l}\text { Peaceful } \\
\text { conditions at } \\
\text { home }\end{array}$ & 75.11 & High \\
2. $\begin{array}{l}\text { Peaceful } \\
\text { conditions at } \\
\text { Pesantren }\end{array}$ & 75.66 & High \\
\hline
\end{tabular}

Perceptions on peaceful environments that consist of home and Pesantren are in 
high category, as shown in Table 3. The perception of peaceful condition at home is categorized high with the mean score is $75.11 \%$. That means that the students feel comfortable, safe, not intimidated, and treated well by family members (parents and siblings). Similarly, perception of peaceful conditions at Pesantren is in high category with its average score is $75.66 \%$, it can be concluded that students feel comfortable, safe, not intimidated, and treated well by their friends, teachers/asatidz, and other staffs at school environment.

\section{The Relationship between Peaceful Environmental Conditions and Peaceful Personality of Students}

The relationship between peaceful environments and peaceful personality of students is measured by statistical tests using simple regression test. Based on the simple regression test, the value of the correlation /relationship (R) is 0.824 , and the value of the determination coefficient (R2) is 0.678 , this implies that the influence of the environment or peaceful environmental conditions towards peaceful personality is $67.8 \%$, while the rest is influenced by other variables.

The test result of the influence of environmental conditions on peaceful personality of students shows no real effect (significant) between environmental variables on peaceful personality, in which the F-count is 115.988 with its significance level or probability is $0.000<0.05$, therefore the regression model can be used to predict peaceful personality aspects.

If the peaceful personality of students is influenced by peaceful environmental conditions at home (family) and school, then the final result would show that peaceful environment at home must have its determination coefficient as much as 0.383 or an effect as much as $38.3 \%$ on the character building of students. It shows different result when the peaceful environmental conditions at school were tested, in which the result shows that the determination coefficient (R2) is 0.591 or they have influence as much as $59.1 \%$ on students. Peaceful environmental conditions at school have greater influence on students than peaceful environmental conditions at home.

The different scores of the influence of peaceful environmental conditions at home and school (Pesantren) on students occurs since not all students stay in school dormitory, but most of them stayed in the dormitory. Among 57 respondents, as many as 39 students live in dormitories, while the rest as many as 18 students do not, or $68 \%$ of students live at dorms and $32 \%$ of them do not. Among 39 students live in the dormitories, 21 of them are male students, and 18 students are female who live in separate dormitories.

\section{Reciprocity of Environmental Condition and Peaceful Personality of Students}

Home, school and interactions within these two environments, are a series of peaceful character-building synergies of an individual. Especially in school environment, the combination of the synergies is slightly different. During their staying at Pesantren, students have large family members that consist of friends and teachers, yet some time they will still stay with their family during school holidays. The portion of the influence of these factors relatively depends on absorption level of each student which is different to one another. The factors that determine the absorption level are comfort and individual interest to stay in the environment.

Generally, based on the result of study, the value of the influence of peaceful environmental conditions both at home and Pesantren have similar significant influences on students' character, in which the score is $67.8 \%$. However if they are calculated separately the value of peaceful environmental conditions of Pesantren, that is $59.1 \%$, is greater than the contribution of homes which is $38.6 \%$. The difference of the influence degrees is understandable 
considering the interaction among students at Pesantren is more than the proportion of interaction at home, in terms of time and meetings. Among 57 respondents, the majority of respondents, or 39 of them live dorms while the rest return to their homes around Garut.

The students who stay in dorms are not only from Garut, many of them also come from different cities, such as Bogor, Bandung, Sukabumi, Tangerang, and other cities. They usually go home during semester holidays and eid Mubarak.

The great influence of peaceful environmental conditions gives a logical consequence: they are considered as the major determinant for the peace of all students, thus it is important to keep environmental conditions conducive to peaceful personality of students. It is not an easy task for both school managers and teachers, because of character diversity of a large number of students at the same environment, so it poses a big challenge in interaction. However if the school managers and teachers are able to handle this problem, Pesantren will succeed in scoring great graduates who are best at handling interpersonal interactions with a variety of human characters in the future.

A large proportion of the influence of Pesantren on peaceful personality of students also creates a golden opportunity for Pesantren to create their own environments as a pilot project of social civilization filled with justice, equality, and spiritual peace (religion). If such condition can be successfully created, then the graduates of Pesantren will have peaceful experiences, and are expected to implement the peaceful lifestyle wherever they are.

Although the proportion of the influence of the role of family on students is slightly lower than Pesantren, yet the role of family cannot be ignored. Home or family is the first environment that will never be replaced in a man's throughout his life. Even if it is physically lost, the impression of the house and its members will never be replaced within the memory of an individual, whether it is negative or positive, whether the house is peaceful or unsafe and uncomfortable due to lack of justice and peace in it. Father, mother, and siblings are figures who give a significant influence in the character building of an individual.

The situation and conditions of parenting at home will positively build what so-called attachment. Trust and safe will result in trust to explore the environment (Andayani, 2015). Positive experiences will lead children to positive things as well. Parenting is basically addressed by words, such as warm, sensitive, full acceptance, reciprocal, understanding, and appropriate responses to children needs (Garbarino \& Benn, 1992). The figures of early growth and development of children continue to be a comparison model for future figures of children in other environments. Thus, peaceful condition of family is very important to be applied within the family foundation for the realization of a strong, peaceful, and loveable character-building.

The relationship between peaceful environment and peaceful character is in line with classification criteria of a peaceful society (Bonta, 1996), which are: (1) the presence of a relatively high interpersonal harmony; (2) there is no or a very little numbers of physical violence among adults, adults with children, or between genders; (3) there are conflict resolutions to overcome violence; (4) there is a commitment to prevent violence; (5) there are non-violent ways of parenting. The five criteria can be achieved by like-minded and non-violent individuals.

Both peace and violence were firstly present in human mind (Tillman, 2004). Peaceful mind will invite people to be harmonious, to avoid violence (Akhmad, Kartadinata, \& others, 2016; Sutoyo \& Dhanianto, 2014), to be committed to raise children in a good manner. Love and peace are capable of enlarging the role of parents and teachers at schools in introducing 
children to harmony, and the avoidance of conflict and violence. Peaceful mind will result in the appreciation and respect for others and the individual himself. When social environment respects the individual, then the individual is also likely to appreciate himself as well. Then, if the individual is able to appreciate and be at peace with him (intrapersonal), then he can appreciate others (interpersonal.

The relationship between inner peace and interpersonal peace is reciprocal (Nelson, 2014a). Following are the reasons how intrapersonal peace influences interpersonal peace; 1 ) there is a motivation to treat others as he wants to be treated; 2) Negative emotions such as anger, depression and jealousy can block any peaceful relationship with others; 3)Peaceful conditions create an open-minded and social person; 4) Intrapersonal peace is able to activate associative mental networks; 5) the loss or presence of a sense of security in the past can determine how someone perceives social and peaceful relationships.

Nelson (2014b) added that interpersonal peace also influences intrapersonal peace reciprocally. Following are several reasons how interpersonal peace influences intrapersonal peace; 1) there is a generalization that when someone treats others respectfully, then he will treat himself the same way; 2) peaceful behavior towards others is familiar with emotional expressions such as smiling, laughing, touches, and it may help the individual emotion to develop; 3) peaceful behaviors are cherished by groups and individuals and it may impact on a positive self-evaluation and of course automatically provide positive emotional experiences of the individual; 4) social interaction such as friendship, mutual help, and justice tend to be reciprocal; 5) when society appreciates the individual, then he tends to appreciate himself; and 6) peaceful interpersonal relationships tend to ease intrapersonal conflicts (Nelson, 2014b). The results of study explained previously is in line with the findings of this study; when people's perception on peaceful environmental conditions is high, then the peaceful personality of the individual will be high as well, thus it will have an impact on the peaceful attitudes and behavior of the individual. The value of perception on peaceful environment at home is $75.11 \%$ and $75.66 \%$ for the perception on peaceful environment conditions of Pesantren. The result is not much different from the value of intrapersonal aspects of peace that reached $78.02 \%$ and $76.46 \%$ for interpersonal peace.

The achievement level of peaceful personality and perceptions towards peaceful environments is in line with other findings of this study. Among 57 respondents, there are 37 respondents $(64.91 \%)$ who never had any physical fighting with their friends and 15 respondents $(26.32 \%)$ have committed to minimal fights (1-3 times) in the last one year. This indicates that most respondents are conscious to act peacefully, since they prefer to discuss the issue in dialogue, and they realize that it is better to forgive than facing any conflict. The respondents who ever fought physically reasoned that they committed to the fights because they were offended by rude words, they wanted to do revenge, and they felt cheated and treated badly. These findings make it clear that if there is only a few numbers of physical violence between individuals, that they have their own strategies to solve any conflicts, and are committed to avoiding violence, then a peaceful society will be created by itself.

Although it cannot be denied that based on the research findings, women still dominantly pose peaceful personality. This is based on result of data that as many as 37 respondents were never involved in any big conflict with their friends in the last one year. As many as 22 respondents are female while 15 respondents are male. As for women respondents in the last one year, there are 6 female students who had big arguments with their friends with a frequency of conflicts between 1 to 10 times. In contrast to the numbers of male respondents, who ever get involved in physical fights with their friends, 
which are 14, that mean the numbers of fights are dominated by male students? These data reinforce the assumption that a peaceful personality is more similar to female characters. Mayton (2009) mentions peaceful personality is symbolized by a goddess in Greek mythology named Irene. Irene's character is so loving, caring, peaceful and altruistic.

\section{The Role of Parents in the Development of Peaceful Personality}

It cannot be denied that the importance of the existence and role of parents strongly helps humans' growth and development in their early life. The closeness between an individual and his parents during his early life greatly shaped the development of his endocrine, nervous system, chemical system, pro-social system and behavior (Polan \& Hofer, 1999). Stimulation of parental affection creates a complex system within an individual. Children mental development is the result of their interactions and experiences with their parents. It creates a process called homeostasis, in which the child has a balancing mechanism to do his activities and meet his own needs (Andayani, 2015). Incomplete task in this process or the separation of a child from his parents, especially mothers, in the early growth period will lead to negative consequences in social process, behaviors, and biological neurons of the child. This may lead to a low level of inner peace and imperfect homeostatic mechanisms that will ultimately create barriers to the development of inner peace.

Family is like a child's first educational environment in instilling a peaceful personality trait. Education on peaceful personality is important to be instilled in early age, so that children can have a strong peace building to face social environment, and to avoid conflict and violence. One way to do it is by involving children in the process of peaceful character building.

The success or failure of the child's psychology to embrace the perfection of peaceful character building as the result of his interaction with his parents will be very influential in the next stages of development, where children begin to interact with friends and school environment. In family, children face an important developmental stage, a transition experienced by children from children's development stage to the stage of adolescent development. The success of family to adapt the transition of the child will make the family stronger and function better and vice versa (Martiningtyas \& Paramastri, 2015). The findings of study show that the state of mental peace (state of peacefulness) that was established during parenting will be the main color in building intrapersonal peace that is influential to the pattern of interpersonal interaction. Therefore, the presence and positive role of parenting during the early growth and development of their children, will determine personality of teenagers, both intrapersonal and interpersonally. On the other hand, uncomfortable family condition will have a negative impact on the peaceful personality of the child.

\section{Pesantren and the Development of Students' Peaceful Personality}

Educational institutions, such as schools and Islamic schools are second environment for students after family. Compared to home or family, school/ Pesantren is a socially constructed environment that has several roles: (1) as a place to grow up and socialize with friends, teachers and other figures who are influential; an institution that transfers knowledge that enriches and empowers students' cognitive, affective and psychomotor; (2) an institution that educates normative values in which students are taught about the concepts of right and wrong according to the rules of formal and religious law; and (3) A balance sheet benchmark of social wisdom norms that socially and culturally internalizes moral norms on an appropriateness of an attitude or behavior.

Teacher or educator (asatidz) is a key element in the activation of the role of 
Pesantren. Specification of Pesantren among other schools generally lies in the emphasis of dogmatic religious and reflective spiritual based on Islamic teachings by Prophet Muhammad.

Pesantren is classified as a school which has more responsibilities in scoring graduates who do not only pose external competence, but also a strong moral and spirituality. Therefore when teachers notice that their students show negative symptoms, they (asatidz) will immediately intervene, and guide the students.

One of several attempts made to optimize the role of schools to deal with violence, is through co-scholastic programs (Das \& Das, 2014). Co-scholastic program is needed for the development of affective and psychomotor domains in activities, such as games and sports, arts and music, crafts, and so on. If the education goes well, it can foster a culture of peace, as well as to break the chain of violence in society (Kawuryan \& others, n.d.), it will then spread out widely and turn off the violence.

Culture of violence in society is classified into three types of violence that are interrelated, namely direct violence, structural violence and cultural violence (Galtung, 1996). The three forms of violence are based on causal chain/cycle from one point to another in which the cycles that connect the three forms of violence can be started from any point; from cultural violence to structural violence and connected to direct violence, or vice versa, if one of them is stopped, it will stop other forms of violence (Santoso, 2002). Obviously, education may create peace comprehensively. Through education, peace can be implanted intact in the form of values, life orientation, excellent life skills, emotional health and spiritual, as well as the continuity (culturally) to cross generations, thus it is not only limited to conflict resolutions Childfriendly educational institutions, where violence minimally occurs can help individuals find a peaceful way of life and able to interact socially in a healthy manner.
Signs that violent interaction has been ease always coincide with the re-emergence of self-esteem, future hopes, and trust in society.

\section{CONCLUSIONS AND RECOMMENDATIONS}

The findings of study show the mean of peaceful personality values is categorized high, both in the aspects of intrapersonal and interpersonal peaceful personality. The perception of students on the peaceful environment at Pesantren and home is also relatively high. The factors of peaceful environment at school and home significantly influences peaceful personality of students that influence as much as $67.8 \%$, while the rest, about $32.2 \%$ is contributed by other factors, both internal and external factors. However if the perception of the environmental conditions is split between environmental condition at home and Pesantren, then the influence of Pesantren is greater. This is understandable considering that most of students live in hostels or dormitories owned by Pesantren.

However, although the findings are likely high in the average of peaceful personality, it should not go unnoticed, that there are still several students who still lack of peaceful personality that need a proper comprehensive handling to enhance their peaceful personality. Since it is important to create a child-friendly educational institution, Pesantren must become the frontline figure of a child-friendly educational institution in Indonesia.

Based on statistical findings, it looks like there is a gap in gender, that average male students have a very lower degree of peaceful personality than female students. It is important to actualize a program that is able to enhance the level of peaceful personality among male students, through additional programs such as competitive psychomotor games that is capable of transferring power, physical and emotional energy of students into positive activities. Generally, male students have a warrior gene, in which if they 
are not given the correct allocation of activities, they will release it through negative or destructive activities.

Therefore, it is important for the future studies to conduct a comparative study among other Pesantren or to conduct a comparative study between pesantren and public schools, thus the level of peaceful characteristics of wider numbers of teenage students can be revealed. The next study is expected to expand or explore more about other research approaches, the numbers of respondents, in order to further develop the peaceful characters of teenagers.

\section{REFERENCES}

Akhmad, S. N., Kartadinata, S., \& others. (2016). Perspektif peserta didik tentang kedamaian dan resolusi konflik di sekolah. pedagogia Jurnal Ilmu Pendidikan, 14(2).

Andayani, B. (2015). Tinjauan Pendekatan Ekologi Tentang Perilaku Pengasuhan Orangtua. Buletin Psikologi, 12(1).

An-Na'im, A. (2002). Religion and global civil society: Inherent incompatibility or synergy and interdependence. Global Civil Society, 2002, 55-73.

---. (1996). Toward an Islamic reformation: Civil liberties, human rights, and international law. Syracuse University Press.

Arikunto, S. (2002). Prosedur Suatu Penelitian: Pendekatan Praktek. Edisi Revisi Kelima. Jakarta: Rineka Cipta.

Aron, R. (2003). Peace and war: a theory of international relations. Transaction Publishers.

Ash Shiddieqy, T. M. H. (1999). Islam dan Hak Asasi Manusia. PT. Pustaka Rizki Putra, Semarang.

Asnawir, A. (2012). The correlation between character building and peaceful thinking of students at Darussalam
Islamic boarding school in Ponorogo, East Java. Al-Ta Lim Journal, 19(2), 93-105.

Bayat, A. (2007). Islam and democracy: what is the real question? (Vol. 8). Amsterdam University Press.

Blakemore, S.-J., \& Choudhury, S. (2006). Development of the adolescent brain: implications for executive function and social cognition. Journal of Child Psychology and Psychiatry, 47(3-4), 296-312.

Bonta, B. D. (1996). Conflict resolution among peaceful societies: The culture of peacefulness. Journal of Peace Research, 33(4), 403-420.

Christie, D. J., Wagner, R. V., \& Winter, D. D. (2003). Peace, conflict and violence: Peace psychology for the 21 st century. A Journal of Injury and Violence Prevention, 48.

Das, S., \& Das, K. K. (2014). Imparting peace education through co scholastic activities at the school level. European Scientific Journal.

Diener, E., Ng, W., Harter, J., \& Arora, R. (2010). Wealth and happiness across the world: material prosperity predicts life evaluation, whereas psychosocial prosperity predicts positive feeling. Journal of Personality and Social Psychology, 99(1), 52.

Diener, E., Oishi, S., \& Lucas, R. E. (2003). Personality, culture, and subjective well-being: Emotional and cognitive evaluations of life. Annual Review of Psychology, 54(1), 403-425.

Dusuki, A. W. (2008). What does Islam say about corporate social responsibility. Review of Islamic Economics, 12(1), 5-28.

Elias, N. (2001). Society of individuals. Bloomsbury Publishing USA. 
Farmer, P., Bourgois, P., ScheperHughes, N., Fassin, D., Green, L., Heggenhougen, H. K. Farmer, P. (2004). An anthropology of structural violence. Current Anthropology, 45(3), 305325.

Furqon, P. D. (1999). Statistika terapan untuk penelitian. Alfabeta, Bandung.

Galtung, J. (1996). Peace by peaceful means: Peace and conflict, development and civilization (Vol. 14). Sage.

Gandhi, M. K. (2012). Non-violent resistance. Courier Corporation.

Garbarino, J., \& Benn, J. L. (1992). The ecology of childbearing and childrearing. Children and Families in the Social Environment, 133-177.

Gavazzi, S. (2013). Theory and research pertaining to families with adolescents. In Handbook of marriage and the family (pp. 303-327). Springer.

Halstead, M. (2004). An Islamic concept of education. Comparative Education, 40(4), 517-529.

Hanafi, H. (2002). Alternative conceptions of civil society: A reflective Islamic approach. Alternative Conceptions of Civil Society, 171-189.

Harber, C., \& Muthukrishna, N. (2000). School effectiveness and school improvement in context: The case of South Africa. School Effectiveness and School Improvement, 11(4), 421-434.

Hufad, H. A. (2003). Perilaku Kekerasan: Analisis Menurut Sistem Budaya dan Implikasi Edukatif. MimbarPendidikan, 4.

Isnaini, M. (2013). Internalisasi nilai-nilai pendidikan karakter di madrasah. $A l$ Ta Lim Journal, 20(3), 445-450.
Jackman, M. R. (2002). Violence in social life. Annual Review of Sociology, 28(1), 387-415.

Kawuryan, S. P., \& others. (n.d.). Mengajarkan Perdamaian pada Anak.

Kroger, J. (2007). Identity development: Adolescence through adulthood. Sage.

Martiningtyas, M. A., \& Paramastri, I. (2015). Penerapan Brief Strategic Family Therapy (BSFT) untuk Meningkatkan Komunikasi Orang Tua-Anak. Gadjah Mada Journal of Professional Psychology, 1(1).

Mayton, D. (2009). Nonviolence and peace psychology. Springer.

Meria, A. (2012). Pendidikan Islam di era globalisasi dalam membangun karakter bangsa. Al-Ta Lim Journal, 19(1), 87-92.

Misztal, B. (2013). Trust in modern societies: The search for the bases of social order. John Wiley \& Sons.

Moosa, E. (2001). The dilemma of Islamic rights schemes. Journal of Law and Religion, 15, 185-215.

Mujidin, M. (2012). Garis besar psikologi transpersonal: pandangan tentang manusia dan metode penggalian transpersonal serta aplikasinya dalam dunia pendidikan. humanitas (Jurnal Psikologi Indonesia), 2(1), 54-63.

Nelson, L. L. (2014a). Peaceful personality: Psychological dynamics and core factors. In Personal Peacefulness (pp. 71-106). Springer.

Nelson, L. L. (2014b). Peacefulness as a personality trait. In Personal Peacefulness (pp. 7-43). Springer.

Norcross, J. C., Campbell, L. F., Santrock, J. W., Selagea, F., \& Sommer, R. (2013). Self-help that works: Resources to improve emotional 
health and strengthen relationships. Oxford University Press.

Nugroho, A. S. (2012). Peranan Pesan-tren dalam Pelestarian Nilai Ke-sejarahan Melalui Tradisi Ziarah Walisongo. Pendidikan Agama Islam, 9(1).

Polan, H. J., \& Hofer, M. A. (1999). Psychobiological origins of infant attachment and separation responses.

Ruseffendi, E. T. (2005). Dasar-dasar penelitian pendidikan dan bidang noneksakta lainnya. Bandung: Tarsito.

Rusydiyah, E. F. (2014). Character Education Through the Constructivist Design of Islamic Education Subject at Elementary School Pembangunan Jaya II in Gedangan Sidoarjo. Al-Ta Lim Journal, 21(3), 227-238.

Ryff, C. D., \& Keyes, C. L. M. (1995). The structure of psychological well-being revisited. Journal of Personality and Social Psychology, 69(4), 719.

Ryff, C. D., \& Singer, B. (1996). Psychological well-being: Meaning, measurement, and implications for psychotherapy research. Psychotherapy and Psychosomatics, 65(1), 14-23.

Sameroff, A. (2010). A unified theory of development: A dialectic integration of nature and nurture. Child Development, 81(1), 6-22.

Santoso, T. (2002). Teori-teori kekerasan. Jakarta: Ghalia Indonesia.

Sawyer, S. M., Afifi, R. A., Bearinger, L. H., Blakemore, S.-J., Dick, B., Ezeh, A. C., \& Patton, G. C. (2012). Adolescence: a foundation for future health. The Lancet, 379(9826), 16301640.

Sims, G. K., Nelson, L. L., \& Puopolo, M. R. (2014). Introduction to Personal Peacefulness: Psychological
Perspectives. In Personal Peacefulness (pp. 1-6). Springer. R

Singh, Y. K. (2008). Philosophical foundation of education. APH Publishing.

Siregar, S. (2005). Statistik terapan untuk penelitian. Jakarta: PT Gramedia Widiasarana Indonesia.

Smith, E. J. (2006). The strength-based counseling model. The Counseling Psychologist, 34(1), 13-79.

Sukmadinata, N. S. (2007). Metode penelitian. Bandung: PT Remaja Rosda Karya.

Sutoyo, A., \& Dhanianto, I. (2014). The development of student spiritual competency in secondary school through comprehensive guidance and counseling program.

Tillman, D. (2004). Pendidikan Nilai untuk Kaum Dewasa-Muda. Jakarta: Gramedia Widiasarana Indonesia.

Trinova, Z., \& others. (2016). The Contributions of Quranic Tahfidz to Mental Health. Al-Ta Lim Journal, 23(3), 260-270.

Wheeler, J. J., Mayton, M. R., Carter, S. L., Chitiyo, M., Menendez, A. L., \& Huang, A. (2009). An assessment of treatment integrity in behavioral intervention studies conducted with persons with mental retardation. Education and Training in Developmental Disabilities, 187-195.

Wulf, H. (2004). Security sector reform in developing and transitional countries. Berghof Research Center for Constructive Conflict Management, 5.

Zarrett, N., \& Eccles, J. (2006). The passage to adulthood: Challenges of late adolescence. New Directions for Student Leadership, 2006 (111), 1328. 